\title{
Oficio de Ángel, de Miguel Barnet: la memoria en un espejo fragmentado
}

In: Bulletin Hispanique. Tome 103, º2, 2001. pp. 593-606.

\section{Resumen}

La evocación infantil y juventil le ha servido al escritor cubano Miguel Barnet como recurso para articular un discurso fragmentado que oscila entre el género testimonial y la escritura autobiográfica. Oficio de Ángel (1989) es un testimonio que adopta la forma de la ficción y una novela que recrea engañosamente la vida real.

\section{Résumé}

L'écrivain cubain Miguel Barnet se sert de l'évocation de son enfance et de sa jeunesse pour produire un discours fragmenté à mi-chemin entre le témoignage et l'écriture autobiographique. Oficio de Ángel (1989) est un témoignage qui adopte la forme de la fiction et un roman qui recrée trompeusement la vie réelle.

\section{Abstract}

Through the evocation of childhood and adolescence the Cuban writer Miguel Barnet articulates a fragmented discourse that oscillates between testimony and autobiography. Oficio de Ángel (1989) is a testimony that adopts the form of fiction and, at the same time, a novel that deceptively recreates real life.

Citer ce document / Cite this document :

Gutiérrez José Ismael. Oficio de Ángel, de Miguel Barnet: la memoria en un espejo fragmentado. In: Bulletin Hispanique. Tome 103, N², 2001. pp. 593-606.

doi : $10.3406 /$ hispa.2001.5089

http://www.persee.fr/web/revues/home/prescript/article/hispa_0007-4640_2001_num_103_2_5089 


\title{
Oficio de Ángel, de Miguel Barnet: la memoria en un espejo fragmentado
}

\author{
JOSE ISMAEL GUTIÉRREZ \\ Universidad de Las Palmas de Gran Canaria, España
}

L'écrivain cubain Miguel Barnet se sert de l'evocation de son enfance et de sa jeunesse pour produire un discours fragmenté à mi-chemin entre le témoignage et l'écriture autobiographique. Oficio de Ángel (1989) est un témoignage qui adopte la forme de la fiction et un roman qui recrée trompeusement la vie réelle.

La evocacion infantil y juventil le ha servido al escritor cubano Miguel Barnet como recurso para articular un discurso fragmentado que oscila entre el género testimonial y la escritura autobiográfica. Oficio de Ángel (1989) es un testimonio que adopta la forma de la ficción y una novela que recrea engañosamente la vida real.

Through the evocation of childhood and adolescence the Cuban writer Miguel Barnet articulates a fragmented discourse that oscillates between testimony and autobiography. Oficio de Ángel (1989) is a testimony that adopts the form of fiction and, at the same time, a novel that deceptively recreates real life.

Mots-clés : Littérature cubaine - roman de témoignage - autobiographie.

$S$

IEMPRE que nos acercamos a la narrativa barnetiana nos topamos con un débil asidero teórico que impide la clasificación satisfactoria de un cúmulo de experiencias y actividades artísticas cuya característica primordial B. $H i ., \mathrm{n}^{\circ} 2$ - décembre 2001 - p. 593 à 606. 
consiste en una renovada elaboración de múltiples fronteras, móviles y cambiantes. Plantea Julio Rodríguez-Luis que la unión de los términos «novela» $y$ "testimonio" desemboca en una incongruencia que permite la coexistencia de una narración de hechos total o parcialmente ficticios y una declaración legal de ciertas vivencias hechas por un testigo. Aunque no descarta que la autobiografía, la biografía y la novela histórica traten de acontecimientos reales -como, en efecto, sucede-, tales hechos, en tanto el autor los presenta en forma novelada, están sometidos a una ficcionalización ${ }^{1}$.

Si las incongruencias se redujesen a una cuestión terminológica, la solución al problema estaría a la vuelta de la esquina. Sin embargo, las aproximaciones teóricas a la novela-testimonio, incluidas las de los mismos creadores, no cesan de subrayar la dificultad que entraña la definición de una práctica discursiva tan heterodoxa en el marco institucionalizado de «lo literario». La naturaleza escurridiza del "género" parece escamotear cualquier intento de conceptualización definitiva al situarse en una zona intersticial capaz de conciliar historia y literatura, sociología y narración novelesca, realidad y ficción. Ahora bien, si la novela-testimonio se revela de por sí como una modalidad limítrofe y fronteriza, tampoco la autobiografía - género con el que la categoría fundada por Barnet presenta múltiples puntos de contacto- se ve libre de análogos problemas demarcadores que, por limitaciones de espacio, rehusamos abordar aquí ${ }^{2}$.

Traemos a colación el concepto de «autobiografía» porque, desde Biografía de un cimarrón (1966), emparentada con lo que Stephen Spender denominaría "autobiografía despersonalizada» ${ }^{3}$, Georges May «autobiografía por interpósita persona» ${ }^{4} \mathrm{y}$, más recientemente, Elzbieta Sklodowska ha

1. Julio Rodríguez-Luis. El enfoque documental en la narrativa hispanoamericana. Estudio taxonómico. México, D. F.: Fondo de Cultura Económica, 1997, págs. 9-10.

2. La polémica en torno a la naturaleza y propiedades de la narración autobiográfica ha enfrentado a numerosos teóricos de la literatura. Para un abordaje del tema en Hispanoamérica, véase uno de los escasos estudios dedicados a algunas manifestaciones del género durante los siglos XIX y XX : el de Silvia Molloy Acto de presencia: la escritura autobiográfica en Hispanoamérica (México D. F. : El Colegio de Mëxico-Fondo de Cultura Económica, 1996). Para un contexto geográfico más reducido, consúltense los libros de Hernán Díaz Arrieta (Memorialistas chilenos. Santiago: Zig-Zag, 1960), de Adolfo Prieto (La literatura autobiográfica argentina. Buenos Aires: Centro Editor de América I atina, 1966) y de Raymundo Ramos (Memorias y autobiografias de escritores mexicanos. México D. F. : UNAM, 1967).

3. "Confessions and Autobiography". A. A. V. V. Autobiography. Essays Theoretical and Critical. Edited by James Olney. Princeton: Princeton University Press, 1980, pág. 117.

4. Georges May. La autobiografia. México, D. F.: Fondo de Cultura Económica, 1982, pág. 76 y ss. 
llamado "discurso autobiográfico mediatizado"s, hasta Oficio de ángel (1989), en la que muchos han visto una identificación total del personaje principal con el autor, la narrativa del escritor cubano ha estado marcada, en distintos grados de controversia, por su vinculación con la modalidad autobiográfica. ¿Testimonio, autobiografía? Oficio de ángel contiene elementos que participan de estos y otros géneros colindantes, pero la amplitud y labilidad de las fronteras de una y otra categoría obstaculizan que se encasille la obra bajo un rubro diferente al de «novela», más abarcador quizás y más acorde con ese proceso de ficcionalización que remodela la materia narrativa.

La consideración de Oficio de ángel como una obra que invoca algunos de los fantasmas personales del escritor, además de exorcisar los demonios de la historia cubana reciente, justifica la multiplicidad de perspectivas desplegadas -configuración coral del discurso, cambios bruscos de instancias narrativas, intercalación repentina de anécdotas ajenas a la trama principal, etc. - , así como su estructura fragmentaria ${ }^{6}$. Valga la sospecha formulada por Hugo Achugar, en un sugerente artículo de 1997, de que, a nivel discursivo, las oposiciones individuo/institución, sujeto individual/sujeto social, interés por el sujeto homogéneo versus interés por el sujeto "otro" no resuelven la diferenciación entre autobiografía y testimonio ${ }^{7}$, para legitimar la singularidad de un relato que navega entre los polos de la fórmula autobiográfica, en la que ya ha logrado superarse el dilema verdad/ficción, y el construcción de un yo individual pero con proyección colectiva característica de la novela testimonial o del testimonio ficcionalizado; un relato que dinamita la rigidez de los géneros canónicos tradicionales en busca de una versatilidad formal, que comienza, por ejemplo, en tercera persona para más tarde pasar a la primera (ambas alternan dialógicamente según los registros de una subjetividad cambiante); un relato contrahegemónico sin uniformidad tampoco en los tiempos de los verbos, donde el presente, típico del diario y que recoge

5. Elzbieta Sklodowska. «Miguel Barnet y la novela testimonio». Revista Iberoamericana. 152-3 (julio-diciembre 1990), pág. 1071. Otras taxonomías inventadas por la crítica para captar las ambivalencias de testimonios mediatos son "autobiofonía transcrita", "autobiografía en colaboración" o "heterobiografía» (Philippe Lejeune. Je est un autre. L'autobiographie de la littérature aux médias. Paris: Seuil, 1980, págs. 230-90).

6. Se han ocupado de la obra Ángel Luis Fernández («Oficio de Miguel». Revista de literatura cubana. 17 [julio-diciembre 1991], págs. 5-23), Begoña Huertas Uhagón ("Oficio de ángel: ¿cl tcstimonio cncubicrto?». Casa de las Américas. 185 [octubrc-dicicmbrc 1991], págs. 152-156) y, más brevemente, Abdeslam Azougarh en Miguel Barnet: Rescate e invención de la memoria (Genève: Editions Slatkine, 1996, págs. 163-5), entre otros críticos.

7. Vid. su artículo "Narciso o la representación del otro». Foro Hispánico. 12 (1997), pág. 71 . 
acontecimientos a poca distancia del momento en que ocurren, se combina con el pasado, más frecuente en la memoria y en la autobiografía, catalizando ambas modalidades la duplicidad de miradas que converge en el espejo de la novela: una infantil y otra adulta.

La fluctuación de los tiempos verbales acompaña los movimientos introspectivos de la conciencia en un discurso que evoluciona desde lo centrípeto a lo centrífugo, es decir, desde lo urdido en el mundo interior y próximo (el universo reducido de la intimidad y de los seres cercanos) hasta la invasión de territorios más amplios, habitados por los «otros» ${ }^{8}$. Notamos ligada a las primeras impresiones del sujeto de la enunciación la percepción olfativa (el olor a pajilla del sombrero que lleva el barbero del barrio, el olor a salitre del Malecón, el de flor de magnolio emanado del cajón de un mueble, el aroma de colores del jabón, de la naftalina y del agua de Portugal, el tufillo agridulce proveniente del piso de abajo) y esas sensaciones se funden con los primeros recuerdos (como el de la tía Conchita y Leoncio el joyero haciendo el amor desaforadamente) y un confesado miedo al mar, plasmado en pasajes de enorme brevedad sintáctica y un estilo elíptico. Integrada por un puzzle de «secuencias" textuales de distinta condición literaria, la composición fragmentaria de la obra se enhebra a la forma impresionista y hasta poemática de narrar. Técnica impresionista que recae en la enumeración sintáctica, en la anáfora, en la elipsis lingüística, especialmente de verbos, y en otros recursos que cspcculan en torno a una magnificación de lo trivial. Hablar entonces de narración en estado puro constituiría una inconveniencia crítica, toda vez que la primera parte de la obra, más que a la neta relación de acontecimientos, tiende a la evocación, vehículo idóneo para el desgranamiento de los recuerdos, que se suceden en breves fragmentos narrativos, que se yuxtaponen sin un orden prefijado, ya que la memoria es así: fragmentaria, discontinua, en su tarea de trasladar los hechos ya vividos al presente y refuncionalizarlos. Provista de un espíritu selectivo, la memoria rescata el mundo de la cotidianidad, con sus minucias e intrascendencias: «El viento de la memoria arrasa con lo superfluo. Pero cuando una persona no es otra cosa que un pozo de banalidades, no queda más remedio que sumergirse en él» 9 . Fiel a ese pensamiento, el escaparate traído a la casa de El Vedado se convierte para el niño en un espectáculo cinematográfico. El narrador contempla la

8. Como veremos, este movimiento que va de lo centrípeto a lo centrífugo desplaza también el texto desde el ámbito de la ficción hacia un enraizamiento en la historia y en la realidad de la experiencia cubana.

9. Miguel Barnet. Oficio de ángel. La Habana: Editorial Letras Cubanas, 1989, pág. 14. En adelante, los números que acompañan las citas de la novela remiten a esta edición. 
vida tal y como se refleja en el espejo deformado de este mueble, otrora opulento y cuyas piezas van deteriorándose de generación en generación. También su visión del pasado se ve resquebrajada por los espejos rotos el día en que un seísmo sacude la ciudad. No son los únicos casos de visión espejeante, pues otro de esos objetos, cubierto de manchas bajo los efectos de un ciclón que causa estragos en el mobiliario, le devuelve-desde el recibidor de la casa en donde está colocado- una imagen borrosa de sí mismo; un espejo tan dañado como el que raya el loro Moctezuma y que acaba en el cubo de la basura o como el que reproduce el desconsuelo general tras el robo perpetrado en el apartamento de la familia, "un espejo sin luz, apagado y desnudo" (p. 8). Artilugios inánimes en los que se abstraen tanto él como su madre o sus tías, estas últimas quizás por puro narcisismo, los espejos testimonian el estado anímico de los personajes, invitados a un ensimismamiento reflexivo que favorece el flujo de los recuerdos, materializando así el deseo imperioso del ser de reencontrarse consigo mismo.

$\mathrm{Al}$ margen del leitmotiv del espejo, el narrador acude a las fotos familiares como fuente de información para evocar los rasgos de algunas personas: «[La tía Sunsita] ¡Qué bien está en esta foto, atrapada con su abanico chino y los zapatos de la madre! A su lado el futuro aficionado malacóloco, su hermano menor, y César, el deportista, quien más la vilipendiaba a sus espaldas. Aparecen los tres sonriendo a la cámara" (p. 16). Fotografías enmudecidas ante la indiferencia de todos y con las que a veces se comparan determinados planos de la realidad: "Las noches se pueden recordar aisladas. Son como esas fotografías colocadas en los álbumes, divididas por un ribete negro o una uña en las esquinas" (p. 27). Único testimonio de que dispone a veces para reconstruir de forma incompleta un tiempo y unas personas desconocidas para él, la foto exhibe lo idílico de unas existencias inalcanzables reinventadas en nombre de la nostalgia. A propósito de la aparición de la fotografía en Puerto Rico, señala Edgardo Rodríguez Juliá que ésta «le posibilita al pequeño burgués ese espejismo de inmortalidad que antes sólo le era dable a la nobleza o a la gran burguesía; el retrato de caballete se transforma en la democrática e instantánea imagen Kodak; la pose asumida como exaltación o apoteosis del poder, la fama o el dinero, ahora se convierte en candid camera que pretende recoger la cotidianidad como emblema de bienestar, la celebración del cumpleaños o el debut social como emblemas del éxito en la búsqueda de la felicidad» ${ }^{10}$. Que un narrador $-\mathrm{y}$ por reflejo, también un escritor- que termina abrazando una ideología abiertamente antiburguesa

10. Edgardo Rodríguez Juliá. Puertorriqueños. Álbum de la sagrada familia puertorriqueña a partir de 1898. Madrid: Playor, 1989, pág. 12. 
sienta debilidad por una práctica contraria a los principios que enarbola (la asociada a la recreación en álbumes y en viejas fotos de familia) no ha de resultar incomprensible, pues se explica por los orígenes pequeñoburgueses de su progenie, además del tiempo en que fueron tomadas las instantáneas (la Cuba prerrevolucionaria). Son vestigios de otra época cuya observación no siempre inspira ensoñaciones, sino que a veces suscita inquietantes zozobras, como una de las antiguas fotos de la abuela. Durante su examen se comprueba que ni el documento gráfico, al amarillearse, queda incólume al paso de los años. La reflexión de José Emilio Pacheco sobre la fotografía que cita Barnet (pp. 262-3), en uno de los múltiples juegos intertextuales insertos en la obra, viene a redundar en la misión fatalista de la misma: la fotografía revela, no que el tiempo se ha detenido, sino las ruinas que ocasiona éste al mostrar unos rostros en la actualidad envejecidos o que ya no existen. Su mismo papel, en la medida en que está sujeto al tiempo, acaba manchándose, se resquebraja.

En su viaje al pasado el narrador adulto levanta un puente que lo conduce inexorablemente a la infancia, espejo nebuloso en el que ha quedado fijada la mirada del hombre maduro: "Algunos hombres asocian la infancia con la inmadurez. Creo que soy el mismo hombre de ayer, imprevisible y frágil. Es falso, pues, decir que los nińos imitan los juegos de los grandes» (p. 14). La idea apuntada con estas palabras intensifica un topos anclado en la tradición autobiográfica: el convencimiento de que la niñez, con sus insignificancias, prefigura tendencias afianzadas más tarde en la persona adulta. La confesión de un carácter débil y voluble (rasgos poco admirados en una figura pública) resulta harto significativa en un texto que es más pródigo en detalles selectos de la vida personal de otros individuos que de la suya propia. El lector atento que recorre las páginas de la novela echa en falta algo, intuye que hay cosas que el narrador calla, secretos íntimos celosamente guardados en el archivo de la memoria, lagunas informativas que el despliegue de artificios líricos que barniza el discurso no logra cubrir sin ponerlas en evidencia. A suplir esta reserva memorística no ayudan (sino todo lo contrario) los procedimientos que parcelan los hechos y los disgregan en fragmentos con distinta perspectiva narrativa. Los enfoques que desdoblan la presentación de la retrospectiva desembocan en un vaivén constante entre narrador autobiográfico y una engañosa omnisciencia que deja al sujeto evocador al margen de la historia de la que es principal hilo conductor. Con el distanciamiento de la tercera persona gramatical, el narrador se convierte en testigo imparcial del pasado, en un fotógrafo que, situado en una posición de oculto voyeur, mira la escena captada a través de la lente de una cámara: "Una pareja de ancianos se prepara para cumplir cincuenta años de casados. 
Él lleva una guayabera beige y tabacos en el bolsillo. Es un hombre enfermo, se va a morir y lo sabe, pero sonríe ante el pastel con las cincuenta velitas en forma de palomas" (p. 19).

Se estima conveniente certificar la veracidad de lo que se cuenta ante la posible incredulidad del lector. Al narrarse la extraña desaparición de Petrona, la vieja sirvienta de la familia, tras la muerte del abuelo, o al manifestar el narrador su deseo de retener consigo el recién adquirido loro Moctezuma, se busca poner a buen recaudo la innegable verdad que destilan los hechos: «No quiero dar la impresión de un hombre que ha perdido el sentido de la realidad, pero estoy seguro que eso fue lo que sucedió» (p. 73) ${ }^{11}$. Creamos o no sus palabras, lo cierto es que en la petite histoire que nos ofrece (las noticias sobre los distintos miembros de la familia y las confesiones de su amor por los objetos y por los animales domésticos, por ejemplo) ocupa un lugar destacado en la trama, tejida a modo de rico tapiz, la colección de plácidos sueños y de pesadillas que asaltan por las noches y que paralizan momentáneamente el curso rutinario de la vida real.

Entretanto, la realidad político-social se inmiscuye en los recuerdos familiares: «Sobre la calzada húmeda, un mar de gente con los ojos pegados y sombrillas negras sigue un cortejo fúnebre en cuyo centro va el escueto sarcófago de un joven muerto en una reyerta con la policía. Es el primer mártir de la dictadura batistiana» (p. 87).

Los recorridos del narrador por La Habana lo llevan a adoptar la pose de un guía turístico de otra época. Por otra parte, muy a menudo éste repasa las imágenes de la infancia como el que mira un álbum de fotografías descoloridas, o incluso una pintura, si se trata de un antepasado que el niño no llegó a conocer. No falta algún brote de «realismo mágico» antes de que el relato asuma un tono definitivamente testimonial: "No sé cómo lo lograba, pero Rosalía sentaba a sus chimpancés a la mesa, desayunaba con ellos, los vestía de frac y los ponía en fila india en el soportal de la quinta a fumar tabaco, para congraciarse con el presidente Menocal, visita asidua del matrimonio" (p. 117).

11. Frente al éxito obtenido por los testimonios de Barnet, Elizabeth Burgos-Debray, Elena Poniatowska o Rodolfo Walsh, entre otros, en el proceso de rescate de determinadas verdades del archivo de la memoria, algunas novelas seudotestimoniales de los ochenta acentúan el fracaso del acto de testimoniar. Al declarar el García Márquez de Crónica de una muerte anunciada (1981) la imposibilidad de «recomponer con tantas astillas dispersas el espejo roto de la memoria», desmitifica el contrato veredictivo por el que se regula la escritura testimonial y relativiza el principio de fidelidad histórica (Gabriel García Márquez. Crónica de una muerte anunciada. Buenos Aires: Editorial Sudamericana, 1981, pág. 14). 
Algunas de las mencionadas incursiones urbanas, las que realiza junto a su tío Luisín el malacólogo, están presididas también por la cámara fotográfica (así la visita a un parque zoológico en La Habana); en cambio, los sucesos del mundo occidental están asociados al arte cinematográfico: «Hace unos días vi, en el NODO del cine Duplex, el hundimiento del 'Titanic' y llevo fresca en la memoria la imagen de la confusión y la muerte» (p. 113). Su mismo cerebro acaba erigiéndose en pantalla de proyección por la que cruzan, fugaces, situaciones y personajes del ayer: el padre caminando por un lugar extraño, la madre tendida lánguidamente sobre una cama con almohadones, la tos persistente de una abuela casi moribunda, etc. Imágenes familiares de celuloide que también es habitual encontrar tanto en la mirada asombrada del niño que deforma la realidad como, más tarde, en los sueños intranquilos del joven rebelde.

Cuando la nitidez del recuerdo se ve empañada por un fallo en la técnica fotográfica, como la foto tomada en el colegio con motivo de la graduación, el material constituye un recurso poco fiable. Con las siluetas desdibujadas, el narrador ha de acudir al espejo de su interioridad para reconstruir los personajes evocados: «Sutilmente deslizada sobre mi mesa, la memoria me devuelve los rostros de aquella noche trastocados en imágenes interiores" (p. 183). Desprovisto de material gráfico, invoca a la agrietada memoria para revivir el pasado y para conjurarlo, ya que, paradójicamente, al inmortalizar en la letra impresa los recuerdos, en una especie de simbólico acto homicida, acaba con ellos: "... sólo la literatura es capaz de matar un recuerdo" (p. 184), sentencia el narrador. Prueba de que la escritura acaba por aniquilar al ser que recuerda y hace que el pasado personal se evapore sin remisión es que la Historia, el espacio público, terminan invadiendo pronto el universo privado, cerrado a la contaminación de la realidad externa, del sujeto de la enunciación. El acto comunicativo que empieza con la autorreflexividad del espejo se vuelve ventana a través de la que nos llegan inconfundibles los murmullos del exterior. Un indicio de ello se constata en el relato de las dificultades que pasa el carismático Omar, amigo del narrador, en un momento en que las referencias al revuelto período histórico protagonizado por la dictadura de Batista son cada vez más frecuentes: las bombas estallan en los cines, aparecen muertos tirados en las calles cada mañana, los perseguidos por el régimen tienen que ocultarse para escapar de la férrea vigilancia policial, como es el caso de Juan, el amigo que Richard esconde en su almacén. Diríase que los ojos del joven observador, ahora atentos a los estímulos del entorno, atisban detalles que pasan desapercibidos para los demás, indiferentes a ciertos sectores de la realidad: «O mis ojos tenían 
facultades telescópicas, o eran una cámara de lente cósmico. Me detuve en zonas que los otros no veían o pasaban por alto» (p. 207).

Como la novela abreva, básicamente, en testimonios suministrados por el mismo autor (aunque ficcionalizado) o por seres muy próximos a él, observamos que, a diferencia de las anteriores novelas barnetianas, que parten de entrevistas realizadas a informantes alejados de la experiencia autorial y que, por sus características socioculturales, no tienen acceso a la letra escrita e impresa, Oficio de ángel textualiza el periplo «ejemplarizante» de un individuo privilegiado, quizás no tan representativo desde un punto de vista social o étnico como Esteban Montejo, Rachel, Manuel Ruiz o Julián $\mathrm{Mesa}^{12}$, pero en modo alguno ciego a la problemática político-social en la que está inmerso. De hecho, una vez que la Historia irrumpe brutalmente en el mundo apacible de la cotidianidad, sacudida por las sirenas de las perseguidoras y el zumbido fijo de la radio clandestina, de la deshilvanada sucesión de episodios ubicados en una dimensión atemporal -la de la infancia- se pasa a los hechos localizados en fechas precisas, sometidos a la datación cronológica. El «yo» se transmuta en "nosotros» y la acción sustituye a la actividad puramente imaginativa. Pese a que los "flashes» narrativos aún continúan exhibiendo un estilo elíptico, divagatorio, es visible que desde las insignificancias que poblaban los espejismos de la niñez hasta el grito de "iAbajo la dictadura!» se ha operado una metamorfosis decisiva. La fotografía, esa instantánea que pretende congelar el tiempo, recogerá situaciones menos gratas que los rostros desvaídos de su pintoresca parentela, como la de un rebelde detenido a la fuerza por los verdugos del poder gubernamental, escena que se distingue en una foto sustraída a Mrs. Kate, en la que han quedado documentadas para la posteridad las aberraciones cometidas por los sabuesos del dictador.

Hemos apuntado que en ocasiones la narración alcanza un elevado grado de despersonalización. El recurso de la tercera persona obliga a que el narrador-protagonista se distancie de sí mismo. Ese cambio brusco de persona indica no una oposición radical en la identidad del que escribe, sino que, por el contrario, insinúa el escaso abismo que media entre una y otra, como si fueran las dos caras de una misma moneda. ¿No ha expuesto Mijail Bajtin la afinidad estética entre la primera y la tercera persona en géneros como las memorias, las biografías y las autobiografías, formas canónicas con que la novela «burguesa en estado puro» se hace cargo de la escisión del yo? En efecto, para el crítico ruso la voz autorial se intercambia espacialmente;

12. Protagonistas de las novelas Biografia de un cimarrón, Canción de Rachel (1969), Gallego (1981) y La vida real (1986), respectivamente. 
esas voces intercaladas comparten valores de la familia, la humanidad, la nación, el mundo entero, un yo que es simultáneamente un otro. Ese otro que se brinda como modelo posible hace que el personaje alcance su pasado, envuelto en las brumas del ensueño y la memoria ${ }^{13}$. El desdoblamiento de la voz narradora, que se observa como si fuera otro, infunde aparente objetividad a la relación de acontecimientos. Merced a la distancia impuesta por el tiempo, el hecho de hablar de uno mismo como si se tratase de un tercero se parece al acto de contemplarse en el espejo: visión desde fuera. Superficie reflectante -el espejo- en la que creemos reconocer a alguien que se parece (o que se pareció) a nosotros, pero cuyas facciones y gestos evaluamos como si se tratara de una persona con una identidad distinta. La visualización sobre la lámina bruñida, como método de autodescubrimiento, llega a enmarcarse incluso en el ámbito de lo mitológico: «Muchas veces en la soledad del baño vi a Tezcatlipoca, 'gran árbol del espejo', y me miré en él» (p. 164). El espejo le entrega al narrador una figura poco complaciente, cambiante, a medida que va cuajando su compromiso político. Las preocupaciones colectivas dilatan el estrecho marco familiar, lo borran. De cómo uno y otro mundo discurren paralelamente, se imbrican y confunden trata la novela de Barnet.

No se nos pasa desapercibido el hecho de que otras voces, además de la del narrador principal, se apoderan del discurso diversificando el punto de vista. Es el caso del testigo anónimo que rememora la boda de Richard y Elvira (pp. 62-66), de la criada Milagros, que en calidad de testigo marginal, nos cuenta su experiencia en casa del matrimonio (pp. 99-106), del exiliado Richard, padre del narrador, que lamenta su desgracia (pp. 202-4), de la madre de Omar relatando el registro hecho en su casa por la policía y el posterior asesinato de su hijo (pp. 224-229) o de la esposa de Edelmiro, que confiesa cómo su marido abandonó a una antigua novia (Ágata) para casarse con ella (pp. 273-6). El monólogo de la madre de Omar, Asunción, se orienta hacia la segunda persona gramatical, puesto que habla a un silencioso narratario, a un «otro» identificable con la figura del narrador. Tales intervenciones contrapuntísticas quiebran la configuración monolítica de la obra usurpando un protagonismo absoluto a la voz del narrador "principal» y convirtiendo así la novela en un texto polifónico. Otra de esas voces dialógicas es la de la tía Ágata, que desarrolla un monólogo en segunda persona en el que se dirige a su cuñada Elvira (pp. 305-9), o la de la misma Elvira que evoca la euforia colectiva tras la victoria del Movimiento Revolucionario junto a la

13. Mijail Bajtin. Estética de la creación verbal. México D. F.: Siglo XXI Editores, 1982, pág. 136. 
tristeza por los que murieron por la causa (pp. 332-5). De nuevo el padre del narrador-protagonista toma la palabra (pp. 388-393) para justificar la actitud temerosa de su esposa tras el viraje político de la nación, evaluar los logros de la Revolución y referir algunos episodios de la lucha armada. Son testimonios marginales que complementan (y desde luego matizan) la perspectiva casi onmímoda del portavoz principal de la narración, un procedimiento ya ensayado en Canción de Rachel y que, unido a la cita esporádica de frases sustraídas a varios escritores de prestigio (Julio Ramón Ribeyro, Calvert Casey, José Emilio Pacheco, Marguerite Yourcenar...), incrementa el dialogismo y la polifonía del texto por obra de la forma en que la alteridad de dichas voces, ajenas a la inventiva del autor de Oficio de ángel pero acopladas al libro con el fin de presentar una realidad refractada, interfiere en las acciones que transcurren en el curso de la historia ${ }^{14}$.

En medio del entramado coral de la novela, construida a base de testimonios henchidos de humanidad -alternados en catorce ocasiones con fragmentos transcritos de diversa autoría, incluidos dos del mismo Barnet, que dialogan con el enunciado propiamente narrativo-, hace su aparición, muy avanzado el libro, la voz implacable y fría de la estadística: «Desde el año 1952 al 1958 fueron conducidos al necrocomio más de seiscientos cadáveres de hombres y mujeres que habían sido objeto de torturas y posteriormente muertos a palos, electrocutados, ahorcados o muertos a balazos, dijo el doctor Muller» (p. 343). El joven rebelde en que se transforma el narrador empieza a olvidarse de su circunstancia concreta para rendir tributo, para someterse por entero a las necesidades exigidas por la realidad recién estrenada en la isla: "En mis ojos cabe ahora mismo la historia del país. Soy depositario de su imagen" (p. 381). Al analizar su trayectoria en el espejo del pasado, ve el reflejo especular de la Historia impreso en él.

Por suerte, poco a poco, y gracias a la misma Historia, se van recomponiendo los pedazos dispersos de la memoria. Los fragmentos disgregados del espejo se juntan uno a uno con el fragor de la Revolución, fuerza unificadora de la conciencia individual y colectiva: "Somos la caja de resonancia de

14. En la planificación del texto como un ramillete de autoridades testimoniantes reside también la pugna entre "escritura" y "oralidad"; el primer factor encarnado en la recreación de acontecimientos objeto de elaboración artística por parte de un sujeto letrado que arma su narración en clave autobiográfica valiéndose de un cúmulo de estrategias codificadas literariamente, mientras que el segundo ingrediente remite a la voz de los ocasionales narradores, de menor cuantía que el narrador principal, que exponen su mediatizado discurso bajo la apariencia de un acto oral, vivo, que está sucediendo en ese instante frente a nosotros. Por esa dicotomía y otras circunstancias subordinadas a la génesis de la obra y al papel del autor, Oficio de ángel se halla a medio camino entre la novela-testimonio y la novela ficcional. 
mucha gente que perdió su voz. Y permanecemos aquí, frente a las rocas como un par de jinetes sobre una cresta de mar» (p. 404).

De vez en cuando cavila sobre cuál habría sido su destino de haber escogido otro sendero, pero su arraigada militancia le proporciona un bienestar que ahuyenta la añoranza de haber conocido una suerte distinta: «Me enredo en la escritura y la imagen se esfuma en el azogue de un espejo enemigo" (p. 404). Siempre el espejo, ya sea para analizar la otredad de un sujeto en el que le cuesta reconocerse, ya sea para atrapar los fantasmas del ayer antes de que se esfumen en el aire o simplemente para hurgar en las claves secretas de su conducta.

De la cita anterior se desprende, por otra parte, que la escritura le sirve de refugio y de válvula de escape para reconciliarse con el mundo y consigo mismo. En este sentido cumple una función similar a la del acontecimiento histórico que en enero de 1959 cambió los destinos del país. Escritura y Revolución van cogidas de la mano en una búsqueda constante y llevada hasta el último extremo de identidad. De la misma manera que existe un paralelismo entre el ya citado fragmentarismo del texto y el fragmentarismo de la vida del personaje, sólo recompuesta al final con el advenimiento de un orden social más justo, se puede hablar también de una equivalencia simbólica entre el acto de escribir, concebido como revolucionario, y la lucha enérgica por la libertad a través de un proceso de concienciación política. De este modo, aunque la obra se distancie de la línea testimonial en la medida en que la ficcionalización del autor conlleva un cambio en el método de trabajo, así como en el producto obtenido de esa labor gestante, la exploración en los recovecos de la propia memoria, que nos devuelve, desgajados, retazos y episodios extraídos de la niñez, la adolescencia y la etapa juvenil -hilvanados por la voz de la primera persona narrativa y, en menor grado, de otrasinteractúa, lo mismo que en las novelas-testimonio, con el acontecer histórico de Cuba. Dicho con otras palabras: si la afirmación de un individuo que expresa su maduración y transformación (a la manera del Bildungsroman) organiza el esquema del que parte la seudoficción autobiográfica creada por Barnet, será su relación con un grupo definido por la opresión que sufre y la lucha que sostiene contra esos factores lo que marque las pautas que conducen hacia el objetivo último: la adhesión del personaje-autobiógrafo a una ideología socialista, aun a riesgo de postergar sus necesidades íntimas, con la consiguiente pérdida de individualidad que eso conlleva.

De estructura fragmentaria y carácter episódico, Oficio de ángel no sólo incursiona en los dominios de la narración falsamente autobiográfica por el uso de un narrador-protagonista, sino que, además, bordea los límites de la escritura memorialista e, incluso, del diario, pese a la ausencia de fechas al 
inicio de cada secuencia del libro. Sin decidirse a culminar la autonomía del espacio literario, la obra prolonga una línea ficcional preocupada por trazar perfiles biográficos y autobiográficos de sujetos intrascendentes iniciada en el área hispanocaribeña de los 80 , según María Julia Daroqui, por el volumen de cuentos El niño aquel (1980) de Senel Paz ${ }^{15}$. Asimismo, por la focalización de una trama que gira en torno a la adolescencia, Oficio de ángel conecta, de acuerdo con Donald L. Shaw, con la narrativa del "postboom» ${ }^{16}$. El vuelo poemático de algunos pasajes, apoyado en técnicas como la repetición anafórica, la brevedad sintáctica o la elipsis de verbos, favorece el tono evocador de gran parte del texto, que mezcla lo real con lo ficticio, lo vivido con lo imaginado. Ciertas partes se abren con una marca lingüística distanciadora - la de la tercera persona- que permite al narrador erguirse en testigo objetivo de lo que ve y observa, hasta que, conforme la mirada se acerca al espejo que reproduce la imagen discontinua pero insistente del pasado, la dirección del punto de vista narrativo se invierte y el yo se inmiscuye en el relato como un personaje más. Por encima de todo, resaltemos la construcción de la instancia narrativa en función de las anécdotas proporcionadas por un sujeto enunciador que, en su papel de protagonista y testigo a la vez, hace de las técnicas del relato una coartada eficaz con la que articular el álbum móvil del discurso, donde los recortes de las secuencias tanto vividas como soñadas en el ayer están pegados sin un criterio riguroso, esa niñez y esa juventud contempladas en el espejo fragmentado de la memoria que una natural disposición a la entrega colectiva reconstruye hasta apagar las voces de la nostalgia. Al final de ese viaje poético al paraíso perdido y del posterior descenso a un «infierno" necesario, el narrador se reconoce otro: "Oigo voces. Me doy cuenta de que no son las del pasado. Con alivio me hundo en un sueño tranquilo. Soy otro ya" (p. 408). Contradicción aparente con las palabras enunciadas más arriba sobre la reproducción que hace el adulto de lo que en el niño se hallaba en estado embrionario; simula, en cierta manera, una negación de sí mismo o de una parcela de su "yo": aquí el "otro" de la novela-testimonio no es un informante extraño interceptado por el mediador letrado; el «otro" es un artificio literario, una entidad intra-

15. Acerca de textos de esta índole, María Julia Daroqui comenta que «se recluyen en el acontecer cotidiano, en las significaciones de los espacios íntimos, en la palabra espontánea llena de juegos paródicos y sutilezas irónicas" (María Julia Daroqui. (Dis)locaciones. Narrativas hibridas del Caribe hispano. Valencia: Tirant lo Blanch-Universitat de València, 1998, págs. 36-7).

16. Donald L. Shaw. Nueva narrativa hispanoamericana. Boom, posboom, posmodernismo. $2^{\text {a }}$ ed. Madrid: Ediciones Cátedra, 1999, pág. 256. 
textual llamada narrador que nace a través del olfato, que más tarde despierta al sentido de la vista y que por último agudiza el oído, y cuya identificación con el autor referencial sólo es viable si aceptamos que los hechos verdaderos, como en toda obra literaria, han quedado desvirtuados con la máscara de la ficción, y que lo que debería ser trasunto fiel del «autor real» es, todo lo más, representación figurativa -si queremos, idealizada- de lo que Wayne C. Booth ha llamado «autor implícito» ${ }^{7}$.

Conocer los primeros pasos en la vida de una persona es indagar en las bases del individuo maduro. Sirve para comprenderlo, para justificarlo. También para cuestionarlo. Por ello, el autobiografismo (real o ficticio) centrado en la infancia o en las peripecias de la adolescencia resulta un filón narrativo plenamente vigente hoy día, como lo demuestra, por ejemplo, la novela del chileno Arturo Fontaine, Cuando éramos inmortales (1998), o la del peruano Jaime Bayly, Yo amo a mi mami (1999). Y ese afán por narrativizar la niñez, casi con toda seguridad, seguirá abasteciéndonos en tiempos futuros de pequeñas joyas literarias como la elaborada por el escritor cubano.

17. Es decir, el cúmulo de imágenes, variables y hasta contradictorias, que el autor real proyecta de sí mismo dentro del texto. Vid. La retórica de la ficción (Barcelona: Antoni Bosch, editor, 1978, págs. 63-81) de Wayne C. Booth. 